\title{
Perception of Lagos State Secondary School Students on Influence and Effectiveness of Sex Education on Sexuality Behaviour
}

\author{
Sanni Omolade. O, Atofojomo Omolade. A, Olaluwoye David. R
}

\begin{abstract}
This study examined the perception of Lagos state secondary school students on influence and effectiveness of sex education on sexuality behaviour. Theoretically, the study is grounded in the Perception theory with focus on selective process theory and Uses and Gratification Theory. Descriptive survey method was adopted and data was collected using self-administered, structured close-ended questionnaire. 480 respondents were randomly selected from eight secondary schools from four local governments in Lagos State, Nigeria. Data collected were analysed using Pearson Product-moment correlation. Results indicated that there is a significant positive relationship between sex education and sexuality behaviour of secondary school students $(r=0.34)$, there is a significant positive relationship between sex education and the effectiveness of sex education to sexual behaviour $(r=0.24)$, and also there is a significant positive relationship between effectiveness of sex education and sexuality behavior of secondary school students. $(r=0.39)$. The results also showed that majority of the students are aware of sex education which has different meaning to them. $63.8 \%$ of the students have received sex education with $53.6 \%$ of the students indicating from their teachers. $83.9 \%$ of the respondents agreed that sex education is relevant in stimulating their interest in sexual behaviour and $75.0 \%$ agreed that sex education is relevant in holding their interest in sexual development. The study recommended that parents/guardians should show more interest in the sexual development of their children/wards. Schools should organise effective communication programmes and seminars about sex education for the secondary school students.
\end{abstract}

Index Terms - Sex education, Sex education sources, Secondary School Students, Lagos State.

\section{INTRODUCTION}

Sex education refers to formal programs of instruction on a wide range of issues relating to human sexuality, including human anatomy, sexual reproduction, sexual intercourse, reproductive health, emotional relations, reproductive rights and responsibilities, abstinence, contraception and other aspects of some human sexual behavior. Common avenues for sex education are parents or caregivers, school programs and public health Campaigns. Sexuality is a fundamental aspect of human life: it has psychological, spiritual, social, economic, political and cultural dimension. Preparing children and young people for the transition to adulthood has always been one of humanity's great challenges, with human

Sanni Omolade. O, Department of Broadcasting, School of Communication, Lagos State University, Lagos, Nigeria

Atofojomo Omolade. A, Department of Broadcasting, School of Communication, Lagos State University, Lagos, Nigeria

Olaluwoye David. R, Department of Broadcasting, School of Communication, Lagos State University, Lagos, Nigeria sexuality and relationship as its core. Today in a world with AIDS, how we meet this challenge is our most important opportunity in breaking the trajectory of the epidemic (UNESCO, 2009).

Sexual and reproductive ill health is a major contribution to the burden of the diseases (STDs/STIs) among young people. Ensuring the sexual and reproductive health of young people makes social and economic sense: HIV infection, other STIs, unintended pregnancy and unsafe abortion; all place substantial burdens on families and communities and upon scarce government resources, and yet such burdens are preventable and reducible. Promoting young people's sexual and reproductive health, including the provision of sex education in schools, is thus a key strategy towards achieving the Millennium Development Goals (MDGs), especially MDG 5 (reducing maternal mortality and achieving universal access to reproduce health) and MDG 6(combating HIV //AIDS) (UNESCO, 2009)

The fact that adolescent is disproportionately affected by the reproductive health morbidity, including HIV AIDS, draws attention to the need for appropriate interventions. At the end of 2001, it was estimated that 11.8 million people aged 15-24 years were living with HIV/AIDS, more than half of all new cases occur among people under age 25 years. Young people are vulnerable to HIV because they are more likely to engage in high-risk behaviors including political, economic, social and cultural facets of life. These risky behaviors are often influenced by societal factors that determine people's vulnerability to infection (UNESCO, 2009). Although previous studies in Nigeria indicate that most secondary schools student are aware of the existence of HIV/AIDS, the problem of misconception and sexual behaviors abound.

Sex education is openness about sex in society where teachers at school, parents at home and the department of education have to listen to, communicate and provide the knowledge about sex education to the secondary school students. These factors (school, parents at home and the department of education) either combined or separated influence the attitude of secondary school students. Secondary school learners view sex education either positively or negatively. To some it is seen as a solution to problem surrounding teenager such as lack of knowledge in contraception, which sometimes results in an unplanned pregnancy, sexually transmitted diseases AIDS, abortions (National Action Committee on Aids, 2005). 
Few young people receive adequate preparation for their sexual lives. This leaves them potentially vulnerable to coercion, abuse and exploitation, unintended pregnancy and sexually transmitted infections (STIs), including HIV. Many young people approach adulthood faced with conflicting and confusing messages about sexuality and gender. This is often exacerbated by embarrassment, silence and disapproval of open discussion of sexual matters by adults, including parents and teachers, at the very time when it is most needed. There are many settings globally where young people are becoming sexually mature and active at an earlier age. They are also marrying later, thereby extending the period of time from sexual maturity until marriage (National Action Committee on Aids, 2005).

The perception of sex education is a very controversial issue in Nigeria society due to the conservative nature of culture. People believe that sex education is equivalents to a social taboo and it influences the secondary school students negatively. But the negative repercussions of a neglect of sex education far outweigh the supposed negative influence of sex education. A lack of basic sex education from relevant sources has in no small measure contributed to the prevalence of Sexually Transmitted Diseases (STDs), and Sexually Transmitted Infections (STIs) such as HIV/AIDS, Syphilis, Gonorrhea, unwanted pregnancies, as well as an insatiable crave by youngsters for sex and other unholy alliances.

This trend has assumed worrisome if not frightening dimensions as young students are forced to drop out of schools with unwanted pregnancies and STDs. This further creates a negative multiplier effect on society as the young fragile girls often contemplate life-threatening abortions or give birth to illegitimate children, most times putting their future in jeopardy, while their male counterparts become social misfits, with tendencies of transmitting the STIs to unsuspecting members of the society. How the youngsters perceive sex education and their behavior and response towards them will determine whether or not there will be a reduction in the social imbalances highlighted above. This study therefore sets out to find out if sex education has any form of influence on secondary school students in Lagos state. In order to understand the perception of secondary school students towards sex education, the study answered the following research questions and hypotheses.

\section{Research Questions}

1.Which sex education source is the most influential to sexuality awareness among secondary school students?

2. To what extent do secondary school students perceive sex education as effective to increasing their knowledge and understanding of human sexuality?

3.To what extent does sex education influence secondary school students' sexuality behaviour?

Statement of Hypotheses

Three Null hypotheses were raised for this study and tested for significance at 0.05 .

HO1: There is no significant relationship between sex education and sexuality behavior of secondary school students.

$\mathrm{HO} 2$ : There is no significant relationship between sex education and the effectiveness of sex education to secondary school students' sexual behaviour.

HO3: There is no significant relationship between effectiveness of sex education and sexuality behavior of secondary school students.

\section{LITERATURE REVIEW}

Sexuality and sex education

Sexuality is a "socializing process, formal or informal, which includes instruction and training in all aspects which may help to form normal and wholesome attitudes, values and ideals in relation to sex" (Kelly \& Morgan-Kidd 2001:486). Collins English dictionary (1991:1418) concurs that sexuality is "the state or quality of being sexual; the possession of sexual potency." Furthermore, sexuality defines the very essence of one's humanity including one's self-image, being male or female, physical looks and reproductive capacity; that is sexuality is a natural part of life. It is about the way we are made, how we feel about ourselves, what roles we play in the society and how we procreate (Ikpe, 2004). Sexuality therefore encompasses all that differentiates a person's gender into either male or female, and involves a person's feelings of self-esteem and body image. Sexuality influences a person's behaviour under different circumstances, as well as his/her ability to relate sexually, especially to people of the opposite sex.

Various schools of thought have given sex education different definitions.Sex education is described by Action Health Inc. (2003:1) cited in Adepoju (2005:3) as "a planned process of education that fosters the acquisition of factual information, the formation of positive attitudes, beliefs and values as well as the development of skills to cope with the, psychological, socio-cultural and spiritual aspects of human sexuality". Adepoju (2005) opined that just as our culture, role models in our families and our friends impact us, so also, the knowledge of religious principles, beliefs, rules and regulations and ethical considerations affect our everyday interactions.

According to Haffner, Debra and Kate (2005) the following were cited as the primary goals of sex education:

- Information which ensures that young people receive reliable and potentially life-saving information from trusted sources about pregnancy and sexually transmitted infections.

- Attitudes, Values, and Insights:Adolescents learn to articulate their sexual attitudes in the context of the expressed values of their families and religious communities, their relationships with family members, and their responsibilities to their families, religious communities, and others.

- Relationships and Interpersonal Skills:the development of interpersonal skills in the areas of communication, decision-making, assertiveness, and peer refusal.

- Responsible Decision-Making: sex education programs provide youth with the skills and knowledge they need to develop their own moral capacity.

Different countries came in contact with sex education at various times and the debate of sexual pleasure as an ethical substance contributed to the 1800's sexual revolution. During that period, women agitated for more debates on issues concerning their sexuality, questioned and revolted against 


\section{World Journal of Innovative Research (WJIR) ISSN: 2454-8236, Volume-5, Issue-1, July 2018 Pages 56-64}

rules and regulations prohibiting the use of contraceptives (Lobizone, 2015). The high occurrence of sexually transmitted diseases was used as the basis of introducing sex education in the schools at that time given the controversy surrounding sex education. At that time, young recipients of sex education were referred to as "victims" because sex education was seen as the gospel of the flesh that could lead to sexual espionage among youths (Lobizone, 2015).

Sex Education in Nigeria

Traditional forms of sex education were practiced in Nigeria, whereby kinship systems and coming-of-age ceremonies were performed where the youth were tutored about manhood and womanhood on cultural and biological basis. However, though issues on sexually transmitted diseases were of great concern but they were barely discussed, and the contraction of them was a big shame and stigma (Adepoju, 2005). The author further opined that the child gets acquainted with issues like family relationships and public manners strictly through the socialization process with very little room for self-expression. As school education expanded, questions were raised on moral pertaining to virginity and abstinence and wondered about the credibility of myths and rigid moral standards that surrounded sexual issues (Adepoju, 2005).

In Nigeria, rapid improvement in communication through the use of telephones, print media and new media has enhanced interpersonal relationships among youths, which had tremendous effect on sexuality issues. Youths now engage in flirting, dating and a variety of sexual behaviors' through different communication channels. Irrespective of these changes, information on sexuality was still regarded dirty and is not discussed openly. However, today, people gradually coming to realise the fact that sexual knowledge can serve as a great weapon against ignorance (Adepoju, 2005). Students and young adolescents between the ages of 12 and 19 years account for 54 million of the Nigerian population, hence the need to educate them on the dangers of the sexually transmitted diseases And HIV/AIDS epidemic.

According to the Minister of Education, a quasi-experimental study to evaluate the impact of the FLHE programme among in-school students in Nigeria was conducted by The Global Fund Round 9 Phase 2 HIV grant in Nigeria between January 2013 and June 2015. The overall objective of the impact evaluation study was to identify proven intervention approaches to promoting sexual and reproductive health of in-school youths for better programming among them (Adedigba, 2017). However, as reported by Adedigba (2017), lack of funding of the initiative brought about the development of a road map to further embellish and sustain the programme into the school system which is yet to be implemented. It was further reiterated that if Nigeria would curb the spread of new HIV infections, reduce teenage pregnancies to change the trajectory of the AIDS epidemic, the continuation of the implementation of the programme which was borne out of the need to equip in-school youth to abstain from pre-marital sex cannot be ignored.

Sex education and Adolescence

The period of adolescence is the transition from childhood to adulthood, and it represents a unique stage in every person's life. Adegoke (2003) opined that at this transition stage, developmental characteristics and sexual behaviours are usually displayed by adolescents which can place them at risk of contracting Sexually Transmitted Diseases (STDs), therefore sex education should be related to them.Jegede and Odumosu (2003:66) opined that sex education should include the nature of love, personal relationship and family life. According to Ibeh and Ikechebulu (2002:105), sex education means education related to anatomy and physiology of reproductive systems, contraception and STDs.

Ojieabu, Erah and Okafor (2008) explained that adolescents' makes up 20 percent of the world population and 85 percent of these live in the developing countries. Adolescence is a period of experimentation which exposes the youths to health risk through irresponsible sexual behaviour, drugs, alcohol, and tobacco use. The fact that adolescents are disproportionately affected by the reproductive health morbidity, including HIV/AIDS, draws attention to the need for appropriate interventions. At the end of 2001, it was estimated that 11.8 million people aged $15-$ 24 years were living with HIV/AIDS, and more than half of all new cases occur among people under age 25 years.

Young people are vulnerable to HIV because they are more likely to engage in high - risk sexuality and other behaviours including political, economic, social and cultural facets of life. These risky behaviours are often influenced by societal factors that determine the vulnerability of young people to infection. Previous studies in Nigeria indicate that most secondary schools students are aware of the existence of HIV/AIDS, but the problem of misconception and sexual behaviour abound. With this in mind, UNICEF/UNAIDS/WHO (2002:7) emphasis that, "establishing healthy patterns from the start is easier than changing risky behaviours already entrenched." Sex education should commence at the pre-puberty stage, between 10 and 14 years of age, when the young adolescent is more receptive and more likely to adopt what is being taught (UNICEF/UNAIDS/WHO, 2002:7). In 2007, the Minister of Health in Nigeria as cited inQuisbert (2013) opined that, "Nigerian government policy at the national level recognizes the pressing sexual and reproductive health (SRH) needs of young people" and therefore acted on its policy commitments.

According UNESCO $(2010,2012)$ reports, Nigeria is recognized as "one of few countries that have translated national policies on school-based Comprehensive Sexuality Education (CSE) into near-nationwide implementation". The CSE program is known as the Family Life HIV Education (FLHE) curriculum and has been introduced in more than 30 states of the federation, but with considerable variation between states and within schools in terms of methodology, content and quality of teaching (UNESCO, 2012).

Teacher/school Based Sex Education

Secondary school learners may not realize the impact that unsafe sexual practices, STDs and HIV/AIDS may have on their lives. Young people cannot protect themselves if they do not know the facts about HIV/AIDS. As purported by the 
(World Bank 2002:30): "schools may often be the only place where adolescents can obtain accurate information on reproductive health". In focus groups of African American and Latino adolescents conducted by Aarons and Jenkins (2002), the majority of the participants reported having sex education in the school but said it was inadequate because the curriculum dealt with reproductive and not relationships and feelings. School personnel were viewed as out of touch, not trustworthy, not credible. Chief complaints from students were that the school programs were not comprehensive, information was too sterile and negative and that programs focused too much on the textbooks rather than the realities of sex and relationships. Positives experiences with sex education were equated to the directness and openness of the teacher.In another study, Eastern European youths who rely on teachers, siblings and nurses to learn about sex are less likely to report a need for more sex and relationships education. This confirms findings from other studies which identify that school professionals and healthcare providersare key sources of sex and relationships education (Nonoyama, Tsurugi, Shirai, Ishikawa and Horiguchi, 2005).

Sex education and parents

Sex education has rarely been a comfortable topic for parent-child communication. Many parents are unwilling to talk about sex or uncomfortable doing so, or they may lack the knowledge themselves. Many barriers might prevent open communication between parents and children about sexual issues. For example, in a report of UNICEF/UNAIDS/WHO 2002:26, it was opined that adults fear that informing young adolescents about sex and teaching them how to protect themselves will make them sexually active. Parents play a passive role in providing information to their children, yet they are expected to be key players in this role. This is because sex in most African societies is a taboo subject between parents and children. In urban areas most parents are working and spend little time with their children. Children therefore spend their time with grandparents or other persons entrusted with their care, yet communication about sex and sexuality are a silent wave (UNICEF, 2002:11).

International literature highlights the fact that parents' and guardians' involvement in sex and relationships education, for example, is a predictor for delayed sexual debut and the use of contraception at first sex (Aspy, Vesely, Oman, Rodine, Marshall, and McLeroy,2007). Although parents overall have not been found to be highly influential socialization agents in the sexual socialization of their adolescents, mother compared to fathers have been identified as a source of information (primarily for women) on topics such as pregnancy, birth control, and menstruation (Aarons and Jenkins, 2002). Jordan, Price and Fitzgerald (2000) conducted research on rural parents and, of the respondents, only $90 \%$ believed most parents adequately communicate with their adolescents about sexual issues. In addition, 20\% were "uncomfortable "or very uncomfortable when asked about how difficult it was to talk to their adolescent about sexual issues, while $65 \%$ reported being "somewhat" comfortable "or" uncomfortable ".

In another study by Opara and Akani (2012),One hundred and eleven (70.2\%) respondents believed it was the responsibility of both parents to educate their children and over $70 \%$ acknowledged that the home was the best place for such education. $64(40.5 \%)$ believed that 6-10 years was the ideal age for starting sex education while $49 \%$ thought that the ideal age was $11-15$ years. $65 \%$ of respondents discussed sexuality issues with their children at least occasionally, the content mostly involved description of body parts and reproductive organs.

Religious Leaders and Sex Education

According to Greenberg, Bruess, and Haffner (2000); morality, sexual behaviour, pre-marital sexual behaviour, adultery, divorce, contraception, abortion and masturbation are influenced by religious and spiritual beliefs of people. Berne and Huberman (2000) opined that a national sample of 3,000 young people conducted in 1992 indicated that their church programs spent less than 2 hours talking about sexuality. Clergy members have a critical role to play in supporting comprehensive sexuality education in public schools. Many religious traditions understand sexuality as a gift and, as such, try to provide the moral and ethical frameworks for responsible sexual relationships that lead to the flourishing of every human being.

Media and Sex education

The extent of the influence of television, films, men's magazines, women's magazines, paperback books, radio, etc. is undoubtedly far greater than is generally realized. With television, the country's most influential medium, the sexual messages are more obvious to adults. In a poll by "TV Guide," $59 \%$ of respondents said they thought there was too much emphasis on sex in television. Producers also know that sex consistently garners ratings, and, therefore, profits. (http://www.cybercollege.com/sexmesdia.htm).

Sex education and the Internet

The intervention of the Internet and its availability in Nigeria has influenced sexual knowledge of children. Where parents are still unwilling to enter into any form of discourse with their children concerning sex education, the youths have discovered the cyberspace as an arena where sexuality can be experienced, expressed and fantasized. So the cyber cafes are well patronized by youths, whose sole aim is to consume pornography and chat with some unknown men and women. Likewise, the easy availability of video films of pornography nature has led to the increase in indirect sexual experiences (Ikpe, 2004).

\section{THEORETICAL FRAMEWORK}

The study is grounded in Perception theory with focus on selective process theory and Uses and Gratification theory.

The Perception Theory

Mark (2009: 19) defines perception as "being aware enough of a stimulus to attach meaning to it". The awareness comes from an arousal of one of more of one's senses. Miller (1970: 111) defines perception as "the process of becoming aware of objects and relations in the world around us in so far as that awareness depends on sensory process". Folarin (2002) also holds the view that the study of perception led to the discovery of the selectivity processes. He is of the view that each of us tends to perceive and then decode communication messages in the light of our previous experiences and current 


\section{World Journal of Innovative Research (WJIR) \\ ISSN: 2454-8236, Volume-5, Issue-1, July 2018 Pages 56-64}

dispositions, our needs, moods and memories. The theory is relevant to the study especially when viewed against the backdrop of the fact that sex education is communicated. If that be the case, then it means the students will definitely perceive what is communicated to them based on their past experiences, moods, needs and memories. This underlines the importance of the perception theory to the study.

Selective Process Theory

Selective process theory is one of the central tenets of attitude change theory. Lazarsfeld cited in Baran and Davis (2006) found that people seemed to seek out media messages consistent with the values and belief of those around them. These findings implied that people tried to preserve their existing views by avoiding messages that challenge them. Selectivity is the strategy employed by the theory towards removing unwanted communication messages. It is made up of four rings of defenses namely: selective exposure (attention), selective retention, selective perception and selective attention.

Selective Exposure: is people's tendency to expose themselves or attend to media messages that they are in accord with their already held attitudes and beliefs or tendency for a person to expose himself or herself to those communication that are in agreement with the person'.

This theory holds that people seek out information that caters for their own interests, confirms their beliefs and boosts their own ego, while avoiding those that are contrary to their own predispositions and attacks their self-image. This determine which media they use (Folarin, 2002:70). The theory is, not only about selection of media messages, it can also be related to the motives of selection. According to the theory, people tend to select messages that are in agreement with their personal beliefs or messages that tend to satisfy their needs.

Selective Retention: is the process by which audiences remember best and longest messages and information which is consistent with their re-existing attitudes, beliefs and interest. The principle of selective retention states that; people remember more accurately, messages that are favourable to their self-image than they do to messages that are not favorable (Daramola, 2001: 55).

Selective Perception assumes that people will interpret messages in a manner consistent with their pre-existing attitudes and beliefs. This is the recasting of messages so that its meaning is line with the person's interest.

Selective Attention is the ability of individual to develop "Mental Fitters" that screens out vast amount of information that comes his way. The eyes processes information much faster than the brain can interpret. That is why human brain has to select which information to pay attention to at any given time to avoid confusion (Daramola, 2001:51).

The theory of selectivity has relevance to this research work. The theory suggests that secondary school student will select those sex education sources that will support their beliefs and present information appealing to their interest. This implies that selection and perception held by the secondary school students concerning sex education may be owing to the agreement level of the medium with their personal desires or needs.

In addition, selective perception is relevant to this study because the students have the freedom to decide if those sources have any influence on their attitude to sexuality and their sexual behavior.

Uses and Gratification Theory

This theory is concerned with how individuals gratify their own needs through the media use, as well as motives and outcomes associated with media use. The uses and gratification tradition is associated with individual level goals such as information seeking or to facilitate interpersonal communication needs. Uses and gratification theory focuses on individuals in the mass communication process as it respects the intellect and ability of media consumers (Baran and Davis, 2006). Theorists in Uses and Gratifications view people as

active because they are able to examine and evaluate various types of media to accomplish their communication goals (West and Turner, 2007)

Uses and gratification theory is relevant to this research work. The theory assumes that people are active agents who make deliberate choices among media to gratify their needs. According to West and Turner (2007), the theory holds that people actively seek out specific media and specific content to generate specific gratification. In relation to the study, Secondary school students find themselves among competitive media landscape that exists in the country. Hence, they are left with varieties of sex education sources to choose from and they select those ones that appeal to their needs.

\section{METHOD}

The research method employed for this study was descriptive survey method. The population of this study comprised of students in the Junior secondary school and the Senior secondary school in Lagos state, Nigeria. The simple random sampling using the ballot technique was used to select four local governments in Lagos state namely Surulere local government, Ikorodu local government, Alimosho local government and Agege local government. Stratified sampling was used to separate Junior Secondary school (JSS) and Senior secondary school (SSS) and simple random sampling technique was used to select one each of Junior Secondary School and Senior Secondary schools from each of the local government giving a total of eight secondary schools. Simple random sampling was used to choose a total of four hundred and eighty (480) students from the schools to ensure equal representation of male and female students and the classes (JSS1, JSS2, JSS3, and SSS1, SSS2, and SSS3).Questionnaire was used as a data collecting instrument for this study and inferential statistics was used in analyzing the result.

\section{FINDINGS AND DISCUSSION}

Table 1 shows the summary of respondents' profile.

able 1: Profile of Respondents.

\begin{tabular}{|l|l|l|l|}
\hline Items & Options & Frequency & $\begin{array}{l}\text { Percentage } \\
(\boldsymbol{\%})\end{array}$ \\
\hline Gender & Male & 233 & 50.7 \\
& Female & 227 & 49.3 \\
\hline Age (Years) & $9-12$ & 130 & 28.3 \\
& $13-16$ & 264 & 57.4 \\
& $17-20$ & 66 & 14.3 \\
\hline
\end{tabular}




\begin{tabular}{|l|l|l|l|}
\hline Class & JSS1 & 76 & 16.5 \\
& JSS2 & 78 & 17.0 \\
& JSS3 & 76 & 16.5 \\
& SSS1 & 76 & 16.5 \\
& SSS2 & 78 & 17.0 \\
& SSS3 & 76 & 16.5 \\
\hline Religion & Christianity & 242 & 52.6 \\
& Islam & 206 & 44.8 \\
& Traditional & 12 & 2.6 \\
\hline
\end{tabular}

Result from Table 1 reveals that $50.7 \%$ of the students were male while $49.3 \%$ were female.Majority of the students $(57.4 \%)$ fall within the age range of $13-16 y e a r s$, followed by $28.3 \%$ in the age range of $9-12$ years, followed by $14.3 \%$ in the age range of $17-20$ years. Table 1 also shows that each of the classes was represented by about $17 \%$ and majority of the students were Christian with $52.6 \%$ and $44.8 \%$ were Muslims, while $2.6 \%$ of the students were traditionalists.

Table 2: Meaning of sex education to secondary school students

\begin{tabular}{|l|l|l|}
\hline Options & Frequency & Percentage (\%) \\
\hline $\begin{array}{l}\text { Openness about sex in } \\
\text { the society }\end{array}$ & 38 & 8.3 \\
\hline $\begin{array}{l}\text { Awareness about how } \\
\text { to prepare myself for } \\
\text { sexual life }\end{array}$ & 86 & 18.7 \\
\hline $\begin{array}{l}\text { Knowing about } \\
\text { abstinence, } \\
\text { contraception and } \\
\text { sexual intercourse }\end{array}$ & 35.4 \\
\hline $\begin{array}{l}\text { Knowing more about } \\
\text { sexually transmitted } \\
\text { diseases about }\end{array}$ & 45 & 9.8 \\
\hline $\begin{array}{l}\text { Knowing } \\
\text { emotional relationships } \\
\text { and reproductive health }\end{array}$ & 83 & 9.8 \\
\hline All of the above & 18.0 \\
\hline
\end{tabular}

Table 2 reveals that majority of the students perceive sex education to mean 'Knowing about abstinence, contraception and sexual intercourse' while $18.7 \%$ of the students perceive sex to mean 'Openness about sex in the society'. Table 1 also reveals that equal percentage of students $(9.8 \%)$ perceive sex education to mean 'Knowing more about sexually transmitted diseases' and 'Knowing about emotional relationships and reproductive health' respectively while $18.0 \%$ indicated 'All of the above'

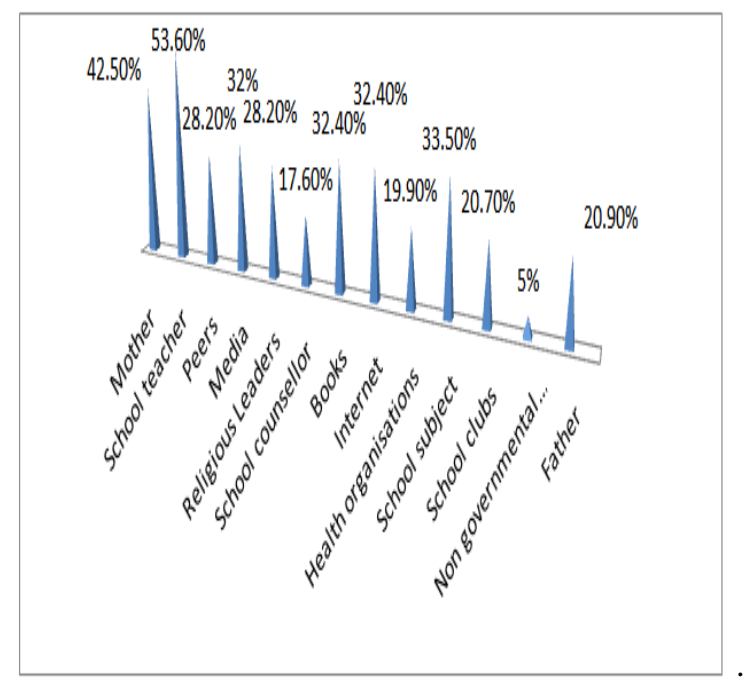

Fig 1: Sources of sex education

Fig 1 reveals the different sources from which the students received sex education. Majority of the students $(53.6 \%)$ indicated their school teachers, followed by mothers $43.5 \%$; this is followed by school subject $33.5 \%$. The students also indicated that they received sex education equally from both Internet and books (32.4\%). This is closely followed by the media $32 \%$, while they indicated peers and religious leaders at $28.2 \%$. The table also shows that $20.9 \%$ of the students received sex education from their fathers while $20.7 \%$ of the students received sex education from the school club. $19.9 \%$ and $17.6 \%$ received sex education from health organisation and school counsellor respectively. The least source the students received sex education was from the Non-governmental organisations (5\%). Figure 1 implies that all the students have received sex education from different sources at one point in their growing up. In the general theme of sex education sources, students believe that they have multiple sources for their sex education.

Research question 1: Which sex education source is the most influential to sexuality awareness among secondary school students?

Table 4: Sex education source most influential to sexuality awareness among secondary school students

\begin{tabular}{|l|c|c|}
\hline Options & $\begin{array}{c}\text { Frequen } \\
\text { cy }\end{array}$ & $\begin{array}{c}\text { Percentage } \\
(\%)\end{array}$ \\
\hline Father & 59 & 12.8 \\
Mother & 98 & 21.3 \\
School Teacher & 75 & 16.3 \\
Peers & 51 & 11.1 \\
Media & 58 & 12.6 \\
Religious & 24 & 5.2 \\
Leaders & 9 & 2.0 \\
School guardian & 37 & 8.0 \\
counselor & 17 & 3.7 \\
Books & 11 & 2.4 \\
Internet & 21 & 4.6 \\
Health & & \\
organisations & & \\
As a subject in & & \\
school & & \\
\hline
\end{tabular}


Table 4 reveals that $21.3 \%$ of the student indicated 'mother' is the most influential sex education source followed by School teacher $(16.3 \%)$, followed by father $(12.8 \%)$ and media $(12.6 \%)$, and peers $11.1 \%$. Least influential is the school guidance counselor $(2.0 \%)$. The result validates Carter and Wojtkiewicz (2000) claim that mothers are more likely to communicate about sex to adolescents than are fathers. Also in accordance to the study of Christopher (2001) cited in Charmaraman\&McKamey (2011), peers are perceived to be another important source of information as adolescents try to make sense of the meaning of sexuality, they often turn to their friends, who generally represent their primary reference group during this stage of their life course.

RQ2: To what extent do secondary school students perceive sex education as effective to increasing their knowledge of human sexuality?

Table5: Effectiveness of sex education to increase in knowledge of human sexuality

\begin{tabular}{|c|c|c|c|}
\hline Items & Options & Frequency & $\begin{array}{l}\text { Percentage } \\
(\%)\end{array}$ \\
\hline $\begin{array}{l}\text { Sex education effective in creating } \\
\text { awareness }\end{array}$ & $\begin{array}{l}\text { Yes } \\
\text { No }\end{array}$ & $\begin{array}{l}386 \\
74\end{array}$ & $\begin{array}{l}83.9 \\
16.1\end{array}$ \\
\hline 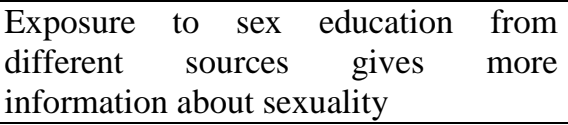 & $\begin{array}{l}\text { Yes } \\
\text { No }\end{array}$ & $\begin{array}{l}379 \\
81\end{array}$ & $\begin{array}{l}82.4 \\
17.6\end{array}$ \\
\hline $\begin{array}{l}\text { Sex education increase understanding } \\
\text { of sexuality }\end{array}$ & $\begin{array}{l}\text { Yes } \\
\text { No }\end{array}$ & $\begin{array}{l}382 \\
78\end{array}$ & $\begin{array}{l}83.0 \\
17.0\end{array}$ \\
\hline $\begin{array}{l}\text { Extent sex education is effective in } \\
\text { increasing understanding of sexuality }\end{array}$ & $\begin{array}{l}\text { Very high extent } \\
\text { High extent } \\
\text { Undecided } \\
\text { Low extent } \\
\text { Very low extent }\end{array}$ & $\begin{array}{l}187 \\
190 \\
14 \\
44 \\
25\end{array}$ & $\begin{array}{l}40.7 \\
41.3 \\
3.0 \\
9.6 \\
5.4 \\
\end{array}$ \\
\hline $\begin{array}{l}\text { Exposure to sex education gives more } \\
\text { knowledge about sexuality }\end{array}$ & $\begin{array}{l}\text { Yes } \\
\text { No }\end{array}$ & $\begin{array}{l}394 \\
66\end{array}$ & $\begin{array}{l}85.6 \\
14.3\end{array}$ \\
\hline
\end{tabular}

Table 5 shows that $83.9 \%$ of the students indicates that sex education is effective in creating awareness on sexuality while $16.1 \%$ indicated that sex education is not effective in creating awareness. Also $83.0 \%$ indicated that sex education increase understanding of sexuality while $17.0 \%$ indicated that sex education does not increase their understanding of sexuality. Furthermore, $85.6 \%$ of the students indicated that exposure to sex education gives more knowledge about sexuality while $14.3 \%$ indicated that exposure to different sex education sources does not give more knowledge about sexuality. The table also shows that sex education is effective in increasing understanding of sexuality by the students to a large extent because of the exposure they have in sex education from different sources. This result validates Escobar-Chaves, Tortolero, Markham, Low, Eiffel and Thickstun (2005) cited in Guzman (2012) claim that many types of media influence

Research Question 3: To what extent does sex education influence secondary school students' sexuality behaviour? sexuality including television, movies, newspaper/magazines, popular music and most recently the internet. The authors claim that the degree to which sex is displayed on television and in other forms of media has increased overtime. Moreover although some information presented about sex in the media may be harmful, the media may also be a source of accurate and helpful information about sex in form of public health messages, about condom use and other safe-sex practices. This result also conforms to the selective exposure theory which claims that there tendency for a person to expose himself or herself to those communications that are in agreement with the person.

\section{Table 6: Influence of sex education on students' sexual behaviour}

\begin{tabular}{|l|l|l|l|}
\hline Items & Options & Frequency & Percentage (\%) \\
\hline Sex education influence sexual behavior & Yes & 386 & 83.9 \\
& No & 74 & 16.1 \\
\hline Sex education is relevant in stimulating interest in sexual & Yes & 382 & 83.0 \\
behaviour & No & 78 & 17.0 \\
\hline Sex education is relevant in holding interest in sexual & Very high extent & 187 & 40.7 \\
behaviour & High extent & 160 & 34.8 \\
& Undecided & 24 & 5.2 \\
& Low extent & 59 & 12.8 \\
\hline
\end{tabular}


Table 6 reveals that $83.9 \%$ of the students indicated that sex education influence their sexual behavior and $83.0 \%$ indicated that sex education is relevant in stimulating their interest in sexual behavior and $75.5 \%$ indicated that that sex education is relevant in stimulating their interest in sexual behavior to a high extent.

HO$_{1}$ : There is no significant relationship between sex education and sexuality behavior of secondary school students.

Table7: Summary of Pearson Product-moment correlation

\begin{tabular}{|c|c|c|c|c|c|c|}
\hline Variable & $\mathbf{N}$ & Mean & Std. D & $\mathbf{r}$ & $\begin{array}{l}\text { Si } \\
\text { g. }\end{array}$ & Remark \\
\hline $\begin{array}{l}\text { Sex education } \\
\text { Sexuality behaviour }\end{array}$ & $\begin{array}{ll} & 46 \\
0^{4} & \\
0^{46} & \end{array}$ & $\begin{array}{l}8.55 \\
18.51\end{array}$ & $\begin{array}{l}3.68 \\
3.48\end{array}$ & .339 & $00^{.0}$ & Significant \\
\hline
\end{tabular}

Table 7 reveals that there is a significant positive relationship between sex education and students sexuality behaviour $(\mathrm{r}=0.34, \mathrm{p}<0.05)$ Therefore $\mathrm{HO}_{1}$ is rejected. The positive relationship implies that sex education brings influence on sexuality behavior of the students. This is in conformity with the selective perception theory that assumes that people will interpret messages in a manner consistent with their pre-existing attitudes and beliefs. This is the recasting of messages so that its meaning is line with the person's interest. This theory holds that people seek out information that caters for their own interests, confirms their beliefs and boosts their own ego, while avoiding those that are contrary to their own predispositions and attacks their self-image (Folarin 2005). According to the theory, people tend to select messages that are in agreement with their personal beliefs or messages that tend to satisfy their needs.

$\mathbf{H O}_{2}$ : There is no significant relationship between sex education and the effectiveness of sex education to secondary school students' sexual behaviour.

Table 8: Summary of Pearson Product-moment correlation

\begin{tabular}{|c|c|c|c|c|c|c|}
\hline Variable & $\mathbf{N}$ & Mean & Std. D & $\mathbf{r}$ & $\begin{array}{l}\text { S } \\
\text { ig. }\end{array}$ & Remark \\
\hline $\begin{array}{l}\text { Sex education } \\
\text { Effectiveness of sex } \\
\text { education to sexual } \\
\text { behaviour }\end{array}$ & $0^{46}$ & $\begin{array}{l}8.55 \\
7.46\end{array}$ & $\begin{array}{l}3.68 \\
1.73\end{array}$ & .243 & $00^{.0}$ & Significant \\
\hline
\end{tabular}

Table 8 reveals that there is a significant positive relationship between sex education and the effectiveness of sex education to sexual behaviour $(\mathrm{r}=0.24, \mathrm{p}<0.05)$ Therefore $\mathrm{HO}_{2}$ is rejected. The positive relationship implies that, the more the students are aware, informed and have knowledge of sex education, the better the effectiveness of sex education to their sexual behavior This may be as a result of the different sources of education the students get information from, which may influence their intentions in engaging in sexual activities. Getting information from different sources especially their parents may reinforce their beliefs

$\mathbf{H O}_{3}$ : There is no significant relationship between effectiveness of sex education and sexuality behavior of secondary school students.

Table 9: Summary of Pearson Product-moment correlation

\begin{tabular}{|c|c|c|c|c|c|c|}
\hline Variable & N & Mean & Std. D & r & Sig. & Remark \\
\hline Sexuality behavior & 460 & 18.51 & 3.48 & .393 & .000 & Significant \\
$\begin{array}{c}\text { Effectiveness of } \\
\text { sex education }\end{array}$ & 460 & 7.46 & 1.73 & & \\
\hline
\end{tabular}

Table 9 reveals that there is a significant positive relationship between effectiveness of sex education and sexuality behavior of secondary school students. ( $r=0.39, \mathrm{p}<$ 0.05) Therefore $\mathrm{HO}_{1}$ is rejected. The positive relationship implies that increase in effectiveness of sex education influences the sexuality behavior of secondary school students.

\section{CONCLUSION}


World Journal of Innovative Research (WJIR)

ISSN: 2454-8236, Volume-5, Issue-1, July 2018 Pages 56-64

Secondary school students are the future of Nigeria who needs sex education. Results from this research establish that most of the secondary school students are interested in sex education and also, most of them are aware of sex education sources which have a positive influence on their sexuality behaviour thereby bringing about improvement in their reproductive health. The study recommends that effective communication about sex education between parents and child is very essential and should be encouraged, and parents should show more interest in the sexual development of their children/wards. Schools should organise effective communication programmes and seminars about sex education for the secondary school students. Guidance and Counselling units of all schools should expose and guide the students through all the available and accessible sex education sources. Religious leaders in church and mosque needs to play a pivotal role in educating the adolescents on what they need to know about sex education with the aim to help the young ones live a better live and put them through on the importance of sex education. Education ministry and Non-governmental organisations should provide greater resources for implementing good quality sex education programmes for secondary school students in Nigeria.

\section{REFERENCES}

[1] Aarons S. J. \& Jenkins, R. R. (2002). Sex, pregnancy, and contraception related motivators and barriers among Latimo and American Youth in Washington .D.C. Sex Education 2(1) 5-30.

[2] Action Health Inc. (AHI), (2003) Comprehensive Sexuality Education: Trainers' Resource Manual. Lagos: AHI

[3] Adedigba, A. (2017). Why sex education should be taught in Nigerian secondary schools - SFH.Premium Times.

https://www.premiumtimesng.com/news/more-news/252977-sex education-taught-nigerian-secondary-schools-sfh.html. Accessed February 19, 2018

[4] Adegoke, A. A. (2003). Adolescents in Africa: Revealing the problems of teenagers in contemporary African society. Ibadan: Hadassah Publishing.

[5] Adepoju, A. (2005). Sexuality Education in Nigeria: Evolution, Challenges and Prospects: Understanding Human Sexuality Seminar Series 3, Lagos: African Regional Sexuality Resource Centre

[6] Aspy, C.B., Vesely, S.K., Oman, R.F., Rodine, S., Marshall, L. \& McLeroy, K. (2007).'Parental Communication and Youth Sexual Behaviour', Journal of Adolescence; 30: 449-466.

[7] Baran, J.B., \& Davis, D.K. (2006). Mass communication theory: Foundation, Ferment and future. (4thed.). New York: Wadsworth.

[8] Berne, L.A, \&Huberman, B.K. (2000). Lessons learned: European approaches to adolescent sexual behavior and responsibility. Journal of sex education and Therapy 25(/2/3)189-199.

[9] Carter, R.S. \& R.A. Wojtkiewicz. (2000). "Parental Involvement and Adolescents' Education: Do Daughters or Sons Get More Help?"

Adolescence 35:29-44.www.sciepub.com/reference/15251 Accessed February 19, 2018

[10] Charmaraman, L., \&McKamey, C. (2011). Urban early adolescent narratives on sexuality: Accidental and intentional influences of family, peers, and the media. Sexuality Research and Social Policy, 8(4), 253-266. doi:10.1007/s13178-011-0052-3.

http://digitalcommons.ric.edu/cgi/viewcontent.cgi?article=1253 \&context=facultypublicat

[11] Daramola, I. (2004). Introduction To Mass Communication. (2nd ed.). Rothan Press Ltd, Lagos.

[12] Escobar-Chaves, S. L., Tortolero, S. R., Markham, C. M., Low, B. J., Eifel, P., \&Thickstun, P. (2005).Affect of the public relations on teen sensual tempers and behaviours. Pediatrics, 116 , 303-326.
[13] Folarin, B. (2002). Theories of Mass Communication: An Introductory text. Lagos: Gabi Concept Ltd

[14] Folarin, B. (2005). Theories Of Mass Communication: An Introductory Text. (3rd ed.).Ibadan: Bakinfol Publications.

[15] Greenberg, J. S, Bruess, C. E and Haffner, D. W, (2000). Exploring the Dimensions of Human Sexuality. Sudbury: Jones and Bartlett Publishers

[16] Guzman, V. B. (2012).Awareness of sources of sexuality schooling and targets of sexuality communication: sociodemographic and cohort effects. In: Tuixachhanghieuvs. http://tuixachhanghieuvs.blogspot.com.ng/ Accessed, February 19,2018

[17] Haffner, Debra, \& Kate, O. A. (2005). Time to Speak: Faith Communities and Sexuality Education, 2nd Ed. (Norwalk, CT: Religious Institute on Sexual Morality, Justice, and Healing, (2005), 25.

[18] Ibeh, C.C. \&Ikechebelu, J.I. (2002). Teenage pregnancy: knowledge and attitude of adolescents in South-East Nigeria Journal of College of Medicine 7(2):104-107.

[19] Ikpe, E. B. (2004). "Human Sexuality in Nigeria: a Historical Perspective" in AFSRC, Human Sexuality in Nigeria: Understanding Human Sexuality Seminar Series No. 1, Lagos: African Regional Sexuality Resource Centre

[20] Jegede, A .S \&Odumosu, O. (2003). Gender and health analysis of sexual behaviour in South Western Nigeria. African Journal of Reproductive Health 7(1):63-70.

[21] Kelly, P.J \& Morgan-Kidd, K. J. (2001). Social influences on the sexualbehaviours of adolescent girls in at-risk circumstances. Journal of Obstetric, Gynaecologic and Neonatal Nursing 30(5):481-489.http://www.ncbi.nlm.nih.gov/pubmed/11572528

[22] Lena, L. (2000). Sexuality Education in Schools: The Swedish debate in historical perspective. Published by Swedish Association for Sex Education with the support of Swedish International Development Co-operation Agency (SIDA)

[23] Lobizone (2015). Origin of Sexuality Education. http://lobizone.com/education-studies/adult-education/origin-ofsexuality-education

[24] Mark, V. (2000). Communication: Theories and applications. Boston: Houghton MiffilinCompany.

[25] Miller, A. (1970): Psychology: The science of mental life. England: Penguine Books.

[26] Nigeria, M. o. H. (2007). National Policy for Health and Development of Adolescents and Young People in Nigeria Abuja, Nigeria.

[27] Nonoyama, M., Tsurugi, Y., Shirai, C., Ishikawa, C. \& Horiguchi, M. (2005). 'Influences of Sex-related Information for STD Prevention', Journal of Adolescent Health; 36: 442- 445.

[28] Quisbert, S. P.H (2013). Scaling up sexuality education in Nigeria: From national policy to nationwide application. (Master's thesis)

https://digital.lib.washington.edu/researchworks/bitstream/handl e/1773/23429/HuaynocaQuisbert_washington_0250O_11858.pd f? sequence $=1 \&$ is Allowed $=$ n Accessed

[29] UNESCO (2009). Young People's Sexual and reproductive health. Paris: UNESO. http://www.cybercollege.com/sexmesdia.htm.

[30] UNESCO. (2010). Levels of success. Case studies of sexuality educationprogrammes. Paris: UNESCO http://unesdoc.unesco.org/images/0018/001884/188495e.pdf

[31] UNESCO. (2012). The challenges and opportunities of scaling up. Paris: UNESCO. http://unesdoc.unesco.org/images/0022/002277/227781E.pdf

[32] West, R. \& Turner, L.H. (2007). Introducing communication theory: Analysis and Application. (3rded.). New York: MC Graw Hill Inc. 